Journal of Universal Language 16-1

March 2015, 49-86

\title{
Plural Formation Strategies in Ígálà
}

\author{
Johnson Folerunso llori \\ University of Lagos, Nigeria
}

\begin{abstract}
Plural formation in Ígálà is interesting in that it is not exclusive to nominals but restrictedly extends to the predicate of the language. This, superficially considered, have resulted in claims in certain quarters that plural formation in Ígálà is unique and structurally different when compared to what obtains in other languages within the Yoruboid group, namely Yoruba and Itsẹkiri. Some studies (e.g., Akinkugbe 1976, 1978) have even claimed that Ígálà plural marking features are relics of the Proto-Yoruba-Igala (PYIG) preserved by the language but already lost by other members of the genetic subgroup. Given this background, this paper examines the various structural manipulations employed in Ígálà to signal and/or mark plurality on lexical items at word and phrase/clause levels. Using a combination of the lexicalist and syntactic approaches to word formation, as in Selkirk's (1982) word syntax and Wunderlich \& Fabri's (1995) minimalist morphology, the paper shows that Ígálà plural formation system is not so distant from what obtains in other Yoruboid languages. It also punctures the claim that the apophony/ablaut plural marking type in Itsẹkiri is a PYIG feature .
\end{abstract}

\footnotetext{
Johnson Fọlọrunṣọ Ilọri

Department of Linguistics, African and Asian Studies, University of Lagos, Lagos, Nigeria Phone: +234 706239 9363; E-mail: jfilori@ gmail.com
}

Received August 18, 2014; Revised February 18, 2015; Accepted March 2, 2015 
The study has fundamental implications for understanding the plural interpretation of words, both lexical and functional, and number agreements in the clause structure of Ígálà language.

Keywords: plural formation, lexicalist, word syntax, minimalist morphology, reduplication, compounding, agreement, vowel deletion, tone transfer, contraction

\section{Introduction}

The plural formation system of Ígálà ${ }^{1}$ appears structurally different from the system employed by other Yoruboid languages, i.e., Yoruba and Itse kiri. This apparently informed the claims in some studies (e.g., Akinkugbe 1976, 1978) that some of its plural marking features are relics of the Proto-Yoruba-Igala (PYIG) features preserved only by the language to the exclusion of other members of the genetic subgroup, and that Ígálà plural formation system could be better understood in terms of animacy hierarchy (Omachonu 2003). Drawing on language internal/cross-linguistic evidence and theoretical insights from both lexical morphology and word syntax approaches to word formation on the one hand and minimalist syntax on the other, this study, contra such claims, shows that Ígálà plural formation system is not so distant from what obtains in those other languages.

The main goal of this paper therefore is to describe and analyse the

\footnotetext{
Igálà is a language of the Defoid /Yoruboid subgroup of West Benue -Congo languages spoken natively in Kogi State in central Nigeria . Other languages in the subgroup are Yorùbá (south-west Nigeria) and Itsẹkiri (south-south Nigeria). Igálà is a three-tone-high, low, and mid-discrete level tone language which employs SVO basic word order.
} 
structural patterns permissible in the formation of plural expressions in Ígálà and, also, show that the ablaut plural derivation type found in Itsẹiri which some earlier studies have branded a PYIG feature is an isolated instance that emanated from influences of her neighbouring Edoid languages.

Before the description and analysis of the derivation of Igala plural nouns and pronouns in sections 3 and 4, a brief explanation of the theoretical approaches adopted for the study is provided in section 2 . Section 5 is dedicated to plural marking in the Igala predicate while section 6 concludes the study.

\section{Models of Description}

This study adopts a combination of the lexicalists' (e.g., Di Sciullo \& Williams 1987) and word syntax (as in Selkirk 1982, Lieber 1992, and Borer 2001) approaches to morphological derivation on the one hand and Noam Chomsky's minimalist syntax and its adaptation for morphological derivation as espoused in Wunderlich \& Fabri's 1995 minimalist morphology on the other. The study neither lean completely on the strong syntactic model as in Leiber (1992) nor on the pure lexicalists' view as it believes following Borer (2001) and Corbett (2001), among others, that there are some morphological/semantic primitives in word formation that are not available to syntax just as there are morpho-syntactic issues that a purely lexicalist approach may not be able to handle. This informs the choice of a combinatorial structural approach hinged on the interaction of syntax and morphology for the study. The choice of the minimalist syntax is to complement the morphological approaches by 


\section{Plural Formation Strategies in Ígálà}

providing explanations for the sacrosanct clausal syntax operations in the plural marking process within the Igálà predicate.

\subsection{Word Syntax and Lexicalists' Morphology}

The word syntax approach holds that structural formation of words is syntactically driven. It contrasts with the pure lexicalists' position that internal composition and relation of word features have no relevance in syntax. In the word syntax approach, morphology is a word internal configuration but that configuration in itself is syntactic in nature (Toman 2001). Lieber (1992: 21) puts this more succinctly when he remarked that

The conceptually simplest possible theory would ... be one in which all morphology is done as part of a theory of syntax ... A truly simple theory of morphology would be one in which ... The theory of syntax ... account for the construction of words.

These two approaches are complementarily employed in the discussions on plurals of nouns and pronouns in this study.

\subsection{Minimalist Syntax and Morphology}

The Minimalist program (MP henceforth) of Chomsky (1995, 1998 , 2002, etc.) is a model of generative grammar which uses smaller number of assumptions that are consistent with the operations that capture the nature of human/natural language syntax. MP assumes that UG operates a model that relies on two basic but simple operations which capture the two fundamental properties of 
language namely, (a) infinite use of finite means and (b) connecting sound with language/meaning. In (a), the lexicon and lexical entries make up the finite means while the operations which the human mind uses to ignite its capacity to build/compute syntactic structures is merge. Each lexical item in the MP lexicon is assumed to posses three sets of features namely the phonetic (Phon), syntactic (Syn), and semantic (Sem) features which go with them into numeration and merge operation. In (b), the connection between sound and meaning refers to the two interfaces, Conceptual-Intentional Interface (CI) and Sensory-Motor Interface (SM), which are more or less similar to PF and LF of earlier generative grammar models.

Merge is a simple mathematical operation which combines selected lexical items from the set in a numeration in binary fashion. Numeration is a field where selected lexical items to be used for syntactic derivation are put. It is from there that such word items are merged in twos to derive syntactic objects. Therefore, merge which is of two types - external and internal-presupposes operation select. External merge involves fresh merger operations sourced directly from the lexicon while internal merge is the internal re-arrangement of already formed syntactic objects (SO). Spell-Out is the process of getting from SO to SM interface. It is at this point that the principle of spelling out copies and the linear ordering of merge products are perfected. It is assumed that merge generates unordered products/trees while the Linear Correspondence Axiom (LCA), Specifier $>$ Head $>$ Complement (Kayne 1994), gets them ordered.

Movement/raising/internal-merge is obligatory for certain constituents in derived SOs to allow for feature-checking operations which must be adequately satisfied for a derivation to converge. Any derivation where there are feature mismatches or constituents which are not properly checked will fail to converge and resultantly crash. 


\section{Plural Formation Strategies in Ígálà}

Economy Principles are the constraints placed on movement of constituents into feature-checking domains. These principles state that movement operations are local and therefore must be as short as possible (i.e., shortest move). Movement itself is defined as attraction as items don't just move but are attracted by some head element for feature checking purpose or lexicalization of light/weak head as in head-head movement.

VP-Internal-Subject Hypothesis assumes that subjects of convergent clauses are base generated inside the VP. It also assumes that the internal structure of the VP comprises two related verbal projections or shells; an inner core VP headed by a lexical verb and an outer $v P$ shell headed by a performative light verb which is usually lexicalized by lexical verbs vide head-to-head V-movement. Agent role is assumed to be base generated in the specifier position of the outer $v P$ shell while other theta roles such as theme, experiencer, patient, etc. are base generated within the inner core VP shell.

It is pertinent to mention at this juncture that since Chomsky (1995), various versions of the MP have attempted to unify syntactic and morphological structures using operation merge. In such approach as that of Wunderilch \& Fabri's minimalist morphology, an affix or morphemic head could be combined through merge with a root/stem to derive a new word of the type/kind of the head. For instance, a tense or plural affix could be merged with a $\mathrm{V}$ or $\mathrm{N}$ root to derive a tensed-V or Plural-N respectively. It is pertinent to mention that the output of such derivation is consistently an $\mathrm{X}^{0}$, i.e., a word, and not an XP, i.e., a phrase or clause. This appears to have partly influenced Wunderilch \& Fabri's (1995: 236) remarks that inflectional morphology is: 
a combinatorial system of underspecified stems and affixes ... controlled by a hierarchy of categories, by general principles of affixation, and by principles that regulate paradigm structures.

All these and other related MP assumptions are deployed alongside relevant morphological processes to illustrate and formalise the analyses and proposals made in this article in relation to plural formation processes in ígálà.

\section{Noun-Plural Formation}

\subsection{Plural of Animate Nouns: Prefixation or Compounding?}

Plurals of animate nouns in Igálà grammar models are identified with two items, àm- and $\grave{a} b$-, commonly analysed as plural affixes in the literature. These supposed affixal items are assumed to be prefixed to animate nouns only to derive the plural forms of such nouns, as illustrated in (1). ${ }^{2}$

${ }^{2}$ Here is a list of abbreviations used in this article:

Comp = Complementizer; $\mathrm{CP}=$ Complementizer Phrase; DP = Determiner Phrase; $\mathrm{D}=$ Determiner; $\mathrm{EPP}=$ Extended Projection Principle; Foc $=$ Focusmarker; Infl = Inflection; IP = Inflection Phrase; pl = plural; plP0 = plural word; pref = prefix; Pred = predicate PredP $=$ Predicate Phrase; Qst $=$ Question marker; $1 \mathrm{sg}=1 \mathrm{st}$ person singular; $2 \mathrm{sg}=2 \mathrm{nd}$ person singular; $3 \mathrm{sg}=3 \mathrm{rd}$ person singular; $3 \mathrm{pl}=$ third person plural; $\varnothing=$ null element; Nom $=$ Nominative; $\mathrm{PF}=$ Phonetic Form; $\mathrm{sg}=$ singular; spec $=$ specifier; Subj $=$ subject; $\mathrm{LF}=$ Logical Form; $\mathrm{vP}=$ Functional light verb phrase; $\mathrm{VP}=$ lexical verb phrase. 
56 Plural Formation Strategies in Ígálà

\begin{tabular}{|c|c|c|c|c|}
\hline a. & $\begin{array}{l}\text { àm- } \\
\alpha \mathrm{pl}\end{array}$ & $\begin{array}{l}\text { ónẹ̀ } \\
\text { person }\end{array}$ & $\rightarrow$ & $\begin{array}{l}\text { àmónẹ̀ } \\
\text { 'persons, people' }\end{array}$ \\
\hline b. & & $\begin{array}{l}\text { ẹla } \\
\text { animal }\end{array}$ & $\rightarrow$ & $\begin{array}{l}\text { àmẹla } \\
\text { 'animals' }\end{array}$ \\
\hline c. & $\begin{array}{l}\grave{a} b- \\
\alpha \mathrm{pl}\end{array}$ & $\begin{array}{l}\text { ògìjo } \\
\text { old person }\end{array}$ & $\rightarrow$ & $\begin{array}{l}\text { àbógìjo } \\
\text { 'old folks' }\end{array}$ \\
\hline d. & & $\begin{array}{l}\text { ímọtọ } \\
\text { child }\end{array}$ & $\rightarrow$ & $\begin{array}{l}\text { àbímọtọ } \\
\text { ‘children' }\end{array}$ \\
\hline
\end{tabular}

Almost all previous studies on Igálà grammar appear unanimous on the claim that àm- and àb- are inflectional plural morphemes simply because they do not change the word class of $\mathrm{N}$ roots to which they are affixed but only inflect on such roots to derive their plural forms. However this analysis is inadequate in that it does not address the issues concerning the form and structural behaviour of àm- and $\grave{a} b$-. In fact, many questions are left begging by the analysis. First of all, the structural distribution of àm- and $a ̀ b$ - is not well defined in that analysis. Despite the fact that the two items are assumed to be mutually exclusive in distribution, there is no morphological or phonological constraint that determines which of them is to be used with a particular noun. The choice appears to be by convention. In an attempt to solve this problem, Omachonu (2003: 203-204) made the following submission:

Whereas àm(á) is used as plural morpheme for both human

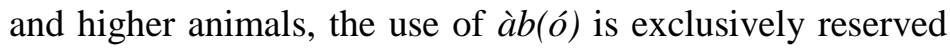
for human nouns. 
This claim however raises two fundamental questions: one, why does àm- works with both human and animal nouns while àb- is exclusive to human nouns? In other words, what is it about àm- that makes its use possible with human and animal nouns? And what is there in $\grave{a} b$ - that restricts its use to human nouns only? Two, how are complex plural nominal words such as àmbógìjo 'elders/old folks,' àmbimotọ 'children,' etc. derived within the context of the plural prefix and animacy hierarchy based theory? Does the language have another plural prefix, say àmb-, which is employed in such derivation? While none of the earlier studies made such claim, their unanimous plural prefix view suggests it.

Implied in Omachonu's (ibid.) statement is the well observed fact that the supposed plural prefixes are truncated forms of àm(a) ' $3 \mathrm{pl} /$ they' and $a ̀ b(o)$ 'folk/people.' This is clearly evident in their meaning as àm- consistently has the ' $3 \mathrm{pl} /$ they' interpretation in its plural marking capacity and context while $\grave{a} b$ - shares the 'folks/people' interpretation with àbó. It is equally clear that the independent contextual use of àma '3pl/they' and àbó 'folk/ people,' illustrated in (2) and (3) below, indicates that they are discrete nominal words, and not prefixes, in the grammar of Ígálà.

(2) a. àbó Igálà

folk/people Igala

'Igala people/folks'

b. Àbó wẹ hà?

folk/people 2sg Qst

'What about your folks/people?' or

'How are your folks/people?' 
58 Plural Formation Strategies in Ígálà

(3) a. Àma ù lí.

$3 \mathrm{pl} \quad 1 \mathrm{sg} \quad$ see

'It was them that I saw.'

b. àma kì dẹ únyí

3pl Comp-3sg be house

'those that are in the house'

If these observations are anything to go by, then the claim that $\grave{a} b$ and $\grave{a} m$ are prefixes in Igala is not sustainable, at least, in the light of relevant language internal evidence.

Another relevant observation on this issue is that almost all of the $\grave{a} b$ - noun-plural forms have àm- counterparts, but none of the àmplural forms have $a b$ - counterparts. This fact is evident in examples (4) and (5).

(4) a. àm- ónú 'king' $\rightarrow$ àmónú/*abónú 'kings'

b. o ọ́ma 'child' $\rightarrow$ àmọ́ma/*abọ́ma 'children'

c. íye 'mother' $\rightarrow$ àmíye/*àbíye 'mothers'

d. éwó 'goat' $\rightarrow$ àméwó/*àbéwó 'goats'

e. ónẹ̀ 'person' $\rightarrow$ àmónẹ̀/*àbónẹ̀ 'persons'

f. àtá 'father' $\rightarrow$ àmàtá/*àbátá 'fathers'

g. ẹ́wẹ 'bird' $\rightarrow$ àmẹ́wẹ/*àbẹ́wẹ 'birds'3

${ }^{3}$ Note that the starred expressions here can be adjudged well-formed if they are not interpreted as plural nouns e.g., àbónú could be interpreted as 'folks/people of the king,' àbẹ́wẹ as 'folks of the bird' (e.g., in moonlight stories), àbíye 'folks/people of the mother,' etc. 
(5) a. àb- ìgbẹ̀lẹ́ 'girl'

b. ímọtọ 'child'

d.

c. ộnẹ̀kẹ̀lẹ 'male/man' $\rightarrow$ àbókẹ̀lẹ/àmónẹ̀kẹ̀lẹ 'men'

$\rightarrow$ àbìgbẹ̀lệàmìgbẹ̀lẹ́ 'girls'

$\rightarrow$ àbímọtọ/àmímọtọ/àmọtọ or àmbímọtọ 'children'

d. $\quad$ ệnẹ ộjọ́ $\quad \rightarrow$ àbọjjọ́/*àmọ́jộ/ámẹ́nẹ́ọ́jọ́ 'God's person' 'God's people'

In recourse to the first question, the reason why àm- is used with both human and animate nouns might not be unconnected with the fact that it is the truncated form of the $3 \mathrm{pl}$ personal pronoun àma which generally refers to all forms of nouns, humans and animals inclusive, in the language. Contrary to claims in earlier studies, restricted forms such as àmolí 'sticks, trees' and àmoòkwúta where àma occurs with non-animate nouns is a confirmation that the referential capability of àma is not even restricted to only human and animate nouns but that it extends to all kinds of nouns in the language. In a similar vein, the exclusive use of àb-, which is the truncated form of the inherently plural noun àbó 'folks/people,' with human nouns logically follows from the naturally expected pattern. As a result, unless a [-HUMAN] noun is personified, e.g., as in fables or moonlight tales, there is no way àbó can be used to refer to it. The analysis in this study therefore straightforwardly accounts for these facts.

The same analysis accounts for the derivation of complex forms like àmbógìjo 'elders/old folks' and àmbímotọ 'children' without having to posit some imaginary plural prefix, say àmb-. Going by the same token that àm- equals àma just as àb-equals àbó, it is only logical to assume that these two free morphemes are merged in the 
complex noun-plural forms, as illustrated in (6).

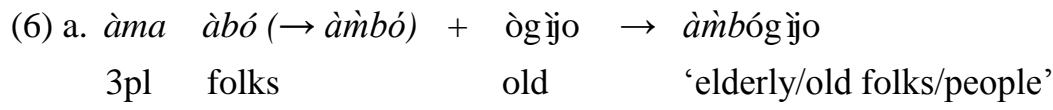

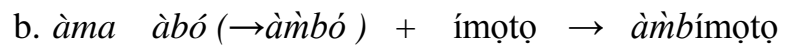
$3 \mathrm{pl}$ folks hild 'children'

The first piece of evidence for the view canvassed in this study is in the discrete literal meaning of each of the input items which is visible in the derived complex outputs. For instance, the morphological inputs of (6a) consists of three items namely àma 'they,' àbó 'folks,' and ògijo 'old/elderly' all of which refer to the same set of individuals. The contracted inherent plural features of àma and àbó derives àmbó which is in turn compounded and contracted with ògìjo to derive àmbógìjo (cf. 6b).

The other piece of evidence that supports this analysis is the tonal transfer at the word juncture between àbó and the following $\mathrm{N}$ merged with it. The high tone on the final vowel of àbó is often retained in the contracted output after the vowel itself has been deleted. For instance, given the fact that the initial vowels of òijo is low-toned, the only principled way to explain the high toned /ó/ in àmbógìjo is to trace it to the high tone carried by the final vowel of àbó. If the assumed prefix àb- is truly the form used in this derivation, we would have to account for the source of that constant high tone on /ó/ in the output. Since àm- shares meaning and form with àma, the logical conclusion that should be drawn is that the two are one and the same morpheme; ditto àb- and àbó for similar reasons. If these observations are correct, then the core morphological process that derives Igálà plural nouns of the àm(a) 
and $\grave{a} b(\sigma)$ type is not prefixation but appositional compounding which subsumes some other phonological processes namely vowel deletion, tone transfer, and contraction. In the process of the derivation, the final vowel of àma and àbó constantly gets deleted. This claim is evident in the following examples in (7).

\begin{tabular}{cll} 
(7) a. àma & éla & $\rightarrow$ àmẹla \\
$3 \mathrm{sg}$ & 'animal & \multicolumn{1}{c}{ 'animals' } \\
b. àma & ónẹ̀ & $\rightarrow$ àmonẹ \\
$3 \mathrm{pl}$ & person & 'persons/people' \\
c. àma & íkélékwu & $\rightarrow$ àmikélékwu \\
$3 \mathrm{pl}$ & rat & 'rats' \\
d. àma & ẹ́wẹ & $\rightarrow$ àmẹwẹ \\
$3 \mathrm{pl}$ & child/baby & 'children' \\
e. àma & ẹ́wẹ & $\rightarrow$ àmẹwẹ \\
$3 \mathrm{pl}$ & bird & 'birds' \\
f. àma & ẹ́ja & $\rightarrow$ àmẹja \\
$3 \mathrm{pl}$ & fish & 'fish' \\
g. àma & ágbójí & $\rightarrow$ àmágbojí \\
$3 \mathrm{pl}$ & leader & 'leaders'
\end{tabular}

Another hole in the plural prefix claim for Igálà is the inherent functional behaviour and distribution of the assumed plural prefixes, àm- and àb-, which appear to make Ígálà uniquely different from 
other languages using singular -plural grammatical distinction , especially for nouns. In languages such as Itshẹki ri (also a member of the Yoruboid group ); Edó e .g., Bini and Uvwiẹ ; Ekiromi, an Edoid language of the Abèsabès group of Northern Akoko; and English; noun plural formation is often effected through apophony/ablaut, a phonological operation which sub-serves a morphological purpose in which a vowel changes to another either at the beginning, middle, or suffix position of a word to denote some kind of grammatical distinction, e.g., plural formation (Radford 2001: 188), as in (8)-(11).

(8) Itshẹkiri
a. o-bìrẹn 'woman'
e-birẹn 'women'
b. o-kẹnrẹn 'man'
ẹ-kẹnrẹn 'men'

(9) Uvwiẹ
a. o-róò
e-róò 'persons/people' 'person'
b. u-kpè 'bed'
$i$-kpè 'beds'

(10) Bini
a. ò-mọ́n 'child'
è-mọ́n 'children' 
$\begin{array}{ll}\text { b. } \begin{array}{l}\text { o-xùò } \\ \text { i-xùò }\end{array} & \text { 'woman' }\end{array}$

(11) Èkìròmi (Àbèsàbès)

a. o-wosi 'husband'

$a$-wosi 'husbands'

b. o-tšói 'witch'

$a$-tšói 'witches'

c. ò-ni 'person'

à-ni 'persons/people ${ }^{4}$

In (8-11), plurals of nouns are formed by alternating the initial vowel of every singular noun with another vowel. Essentially, those alternating vowels are bound morphemes that have no clear meaning until they get attached to their various roots/stems. On the contrary, this kind of alternation does not occur in the process of Igálà nounplural formation, as àm(a) and $\grave{a} b(o)$ are free morphemes with inherent nominal features and unique interpretations of their own, even in isolation.

The implication of this is that the widely assumed plural prefixes (àm- and $a b$-) in Igálà are not affixes after all, but shortened forms of the free morphemes àma and àbó. The two of them are merged and phonologically contracted to derive àmbó used in the derivation of forms like àmbógìjo 'elders/old folks' and àmbímoto 'children.' Therefore, what appears as àm-làb- in Ígálà noun-plural results from the contraction between àmalàbó and the $\mathrm{N}$ it pluralizes. The

4 Data on Itshẹkiri, Uvwie, and Bini were adapted from Omamor (1976). 
contraction evident in this process is triggered by the phonological constraint on Igálà nouns that they are obligatorily vowel initialled. Compounding àmalàbó with a noun triggers contraction which consequently induces the deletion of the final vowel of àmalàbó leaving the truncated superficial form identified as prefixes in the literature (see 7a-g).

Akinkugbe (1976: 16) claimed that the Itshẹkiri example (8a-b), which happens to be the only set of plural formation of that type in the language (Omamor 1976: 39), is a relic of the PYIG noun -plural feature preserved by Itshẹkiri and Igálà but which Yorùbá and its diversified dialects have lost. This view is not sustainable for the following reasons: first, the assumed Igálà plural prefixes are totally different in form and behaviour from the apophony type found in Itshẹkiri; second, the apophony example in Itsẹkiri is not only restricted to the two examples mentioned but consistent with those of Edoid languages where singular -plural vowel prefix alternation is highly productive (Elugbe 1973). Given the fact that Itshẹkiri homeland is geographically surrounded by Edo clans, it would be illogical to look elsewhere for the source of the Itshẹkiri's highly restricted ablaut noun -plural feature . Although Akinkugbe maintained that the Edoid languages which are neighbours to Itshẹkiri only help it to preserve the feature, such claim also can not be sustained because no other member of the Yoruboid group attests that imaginary PYIG feature, not even Igálà. The restricted nature of the examples found in Itshẹkiri and the similarities between Igálà and Yorùbá noun-plural formation processes overwhelmingly point to the Edoid source of the isolated Itshẹkiri ablaut examples

If these observations are anything to go by, then, the derivation of plural nouns in Igálà is not far away from what obtains in Yorùbá where àwọn '3pl, they' (a cognate of Igálà àma) immediately 
precedes a noun to pluralize it. The morphophonemic contrast between Igálà and Yorùbá in such context is illustrated in (12) and (13).

(12) Igálà
a. àma
éwẹ
$\rightarrow \quad$ àmẹ́wẹ
$3 \mathrm{pl}$
bird
'birds'

b. àma itíchà $\rightarrow$ àmítíchà

$3 \mathrm{pl}$ teacher 'teachers'

$\begin{array}{clll}\text { c. àma } & \text { ójí } & \rightarrow & \begin{array}{l}\text { àmójí } \\ \text { 'thieves' }\end{array}\end{array}$

(13) Yorùbá
a. àwọn
eyẹ
$\rightarrow \quad$ àwẹnẹnyẹ
$3 \mathrm{pl}$
bird
'birds'

b. àwon olùkọ́ $\rightarrow$ àwononlùkọ́

$3 \mathrm{pl}$ teacher 'teachers'

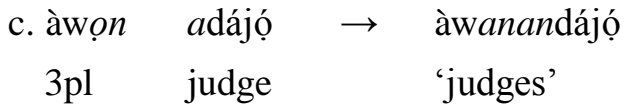

In the Yorùbá example (13a-c), the final nasal vowel of àwọn is

\footnotetext{
${ }^{5}$ Note that this type of expression is possible only in fast speech (cf. pín epo $\rightarrow$ pénpo 'to divide palm-oil'). In slow/normal speech, both àwọn and the $\mathrm{N}$ immediately following it may be pronounced discretely. See Awobuluyì \& Oyebade (1995) for deeper insights on nasalization and denasalization in Yorùbá.
} 
not deleted, rather, it assimilates to the initial vowel of the noun it pluralizes while retaining its nasality which the initial vowel of the $\mathrm{N}$ also assimilates. On the other hand, apart from the fact that there is no significant vowel nasality in Ígálà (Akinkugbe 1978, Omachonu 2001), the final oral vowel of àma is simply deleted while it contracts with the lexical noun it pluralizes.

When àbó is used in Igálà to derive the plural of a noun, its final vowel, /ó/, often deletes without the high tone which is then transferred to the initial vowel of the pluralized noun, as exemplified in (14).

$\begin{array}{rlll}\begin{aligned} \text { a. àbó } \\ \text { folk }\end{aligned} & \text { ògìjo } & \rightarrow & \begin{array}{l}\text { àbógìjo } \\ \text { 'elders / old folks' }\end{array} \\ \text { b. àbó } & \text { ímọtọ } & \rightarrow & \text { àbímọtọ } \\ \text { folk } & \text { child } & & \text { 'children (folk)' }\end{array}$

We therefore conclude that if àm and $a b$ are plural morphemes at all in Igálà, they are not bound or inflectional morphemes. Rather it would be more intuitively adequate to analyze them as free morphemes and/or nominal words that are in compounding relationship with any lexical noun they pluralize.

\subsection{Plural of Non-Animate Nouns}

\subsubsection{Reduplication Strategy}

Apart from pre-merging the inherently plural àma and/or àbó to animate nouns to derive their plural forms, another strategy used to 
derive plural forms of nouns in Ígálà is reduplication. This strategy is mostly used for non-animate nouns such as trees, stones, hills, etc. and it involves full reduplication. Examples of such word expressions in this category are provided in (15a-d). However, it is equally applicable to animate especially when one wants to emphasize number of people or beings present at a scene as in $(15 \mathrm{e}, \mathrm{f})$.

(15) a. òkwúta 'stone' $\rightarrow$ òkwúta-òkwúta 'stones'

b. ólí 'tree/stick' $\rightarrow$ ólí-ólí 'trees/sticks'

c. úwó 'hill' $\rightarrow$ úwó-úwó 'hills'

d. áji 'river' $\rightarrow$ áji-áji 'rivers'

e. ónẹ̀ 'person' $\rightarrow$ ónẹ-ónẹ̀ 'many people'

f. ónú 'king' $\rightarrow$ ónú-ónú 'kings / many kings'

The full reduplication in this instance involves copying the totality of a word and pre-merging that copy to the original without deleting the original such that both the copy and the root are phonetically realised at spell-out to produce a plural noun interpretation. The logical implication of this is that at some point during the course of derivation, the plural feature is integrated.

To model this derivation, we propose that a null functional plural (pl) head is involved in the process and that the process which is actually syntactic feeds the morphology of the language. The projection is such that the null plural head selects a non-animate noun word, e.g., òkwúta as in (15a), as complement to project the plural form of such word in Igala. This plural head for syntactic reasons (cf. EPP feature saturation in TP) requires a copy of its complement in its specifier position to be a convergent syntactic object thus triggering the raising of the copy of its complement to 
spec-plP ${ }^{\mathrm{o}}$ without deleting the word in its extraction site. The result of these structural steps is what shows up superficially as reduplication of the $\mathrm{N}$, i.e., the non-animate plural nouns in the language. It is pertinent to mention that the null plural head in this projection, though morphologically and semantically present, is not phonetically realised in the derivation. This derivation process is schematically represented in Figure 1.

Figure 1. Full Reduplication Projection

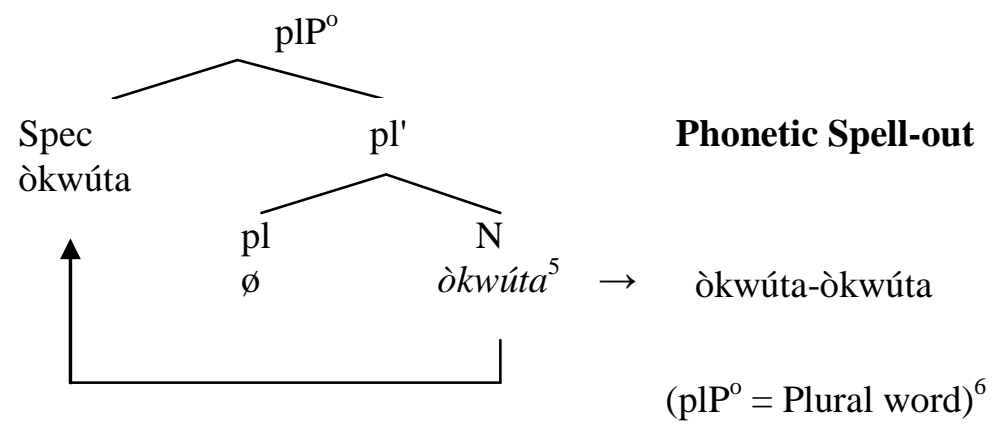

The claim here that the root $\mathrm{N}$ is not deleted after movement appears to be at variance with MP convention that syntactic movement is a process of copy and delete, i.e., any moved item is not just copied but is equally deleted at the extraction site such that it is no longer phonetically realised in that position. We however only need to remind ourselves of predicate fronting processes in syntactic focus, relativization, topicalization, and wh-questions particularly in Yoruboid and other West African languages, to see that this analysis is in order. Predicate fronting as a syntactic process lends itself to

\footnotetext{
${ }^{6}$ Italics is used here to indicate that the singular $\mathrm{N}$ òkwúta is copied but not deleted, i.e., it is retained in-situ VP internally. Note also that $\mathrm{plP}^{\mathrm{o}}$ in this model is an $\mathrm{X}^{0}$ which is equivalent to a word, and not a syntactic phrase.
} 
copying of the verb and raising of such copy to spec-CP without deleting the lexical verb within the VP. Four separate but related patterns which such raised predicates have in this respect especially in West African languages are easily identifiable. The first pattern is found in Gbè languages such as Gúngbè and Fongbè where $\mathrm{V}$ is copied and raised to spec-CP without any change in form while both the copy in spec-CP and the original inside the VP are phonetically realised at spell-out! Witness the example in (16) adapted from Aboh (2007).

(16) a. Kofí dù lésì cè.
Kofi eat rice my
'Kofi ate my rice.'

b. Dù Kofí dù lésì cè. (V-focus)

eat kofi eat rice my

'Kofi ATE my rice.'

In (16), the verb dì 'eat' is copied and raised to spec-CP but its original remains phonetically realised in-situ inside the VP.

The second pattern is the type found in Ígálà in which V is copied and fronted but the copy is nominalised through vowel prefixation as exemplified in (17).

(17) a. Aládi kpa ẹja étí áji (Basic Clause)

Aladi kill fish side river

'Aladi caught fish by the riverside.' 
70 Plural Formation Strategies in Ígálà

b. é-kpa Aládi kpa ẹja étí áji (V-focus) Killing Aladi kill fish side river

'Aladi CAUGHT fish by the riverside.'

Again, the original $\mathrm{V}$ and its raised copy are phonetically realised at spell-out.

The third is the type in Yoruba where the copy of the raised/fronted $\mathrm{V}$ is partially reduplicated, as in (18).

(18) a. Olùkọ́ na Akin.

(Basic Clause)

Teacher beat Akin

'The teacher beats Akin.'

b. Nínà ni olùkọ́ na Akin. (V-focus)

Beating foc Teacher beat Akin

'The Teacher BEATS Akin.'

The fourth pattern is found in languages like $\grave{\varepsilon} w \grave{\varepsilon}$ spoken in Togo and Ghana. It involves full reduplication of the raised/fronted copy of $\mathrm{V}$ as evident in (19) adapted from Ameka (2010).

(19) a. Wò-fò dèví-á.

3sg-hit child-Def

'He beat the child.'

b. Fò-fò wò-fò dèví-á.

red-hit 3sg-hit child-Def

'He BEAT the child.' or

'He gave the child a thorough beating.' 
In a nutshell, all of the four patterns exemplified in (16) to (19) support the analysis in Figure 1 that it is actually possible for the copy of a word to move without deleting the original in-situ. Another likely reason for the somewhat weird nature of the projection proposed in Figure 1 may not be unconnected with the fact that the configuration is not purely syntactic but morpho-syntactic, i.e., a syntactic projection that feeds the morphology of the language. This proposed reduplicative derivation has far reaching implications for other languages that employ similar strategy, e.g., Yoruba in expressions like ilé ńlá-ńlá 'big (big) houses.'

\subsubsection{Use of Quantifiers}

Plural forms of other non-animate nouns in Ígálà are derived through quantification, i.e., by the use of quantifiers or numerals to reference the $\mathrm{N}$. This is achieved by modifying a singular noun with some inherently plural [+PL] quantifier or numeral. The result is a noun interpreted as plural by native speakers. A good example of this is (20).

(20) a. ộyà

'wife'

cf. b. ộyà wéwe/méjī

wife many/two

'many wives / two wives'

See Omachonu (2011) for the Igálà numeral system. 


\section{Plural Formation Strategies in Ígálà}

\section{Plural of Pronouns}

Six groups/types of pronouns, a substantial part of which are morphologically derived, exist in Igálà. These are personal, demonstrative, anaphor, quantifier, interrogative, and genitive pronouns. We shall, however, limit our discussion in this paper to those pronouns that are evidently derived through morphological/ orpho-syntactic processes in the language.

\subsection{Personal Pronouns/Pronominals}

Personal pronouns are so-called because they encode the grammatical properties of person and number. Igálà short and long pronouns are morphologically related. It is evident, as illustrated in the Table 1 below, that Igálà long pronouns are derived from their short counterparts through vowel prefixation.

Table 1. Igálà Pronouns

\begin{tabular}{|c|c|c|c|c|c|}
\hline \multirow{2}{*}{$\begin{array}{c}\text { Short } \\
\text { Pronouns }\end{array}$} & \multirow{2}{*}{ Prefixation } & \multicolumn{3}{|c|}{ Emphatic/Long Pronouns } & \multirow{2}{*}{ Gloss } \\
\cline { 3 - 5 } & & Nominative & Accusative & Genitive & \\
\hline mi & ò/ù- mi $\rightarrow$ & òmi & ùmi & èé-mi & $1 \mathrm{sg}$ \\
wẹ & ù-wẹ $\rightarrow$ & ùwẹ & ùwẹ & èé-wẹ & $2 \mathrm{sg}$ \\
wun & ò/ù-wun $\rightarrow$ & òwun & ùwun/ùu & èé-wun & $3 \mathrm{sg}$ \\
wa & à/ù-wa $\rightarrow$ & àwa & ùwa & èé-wa & $1 \mathrm{pl}$ \\
mẹ & à/ù-mẹ $\rightarrow$ & àmẹ & ùmẹ & èé-mẹ & $2 \mathrm{pl}$ \\
ma & à/ù-ma $\rightarrow$ & àma & ùma & èé-ma & $3 \mathrm{pl}$ \\
\hline
\end{tabular}

Looking at the pronouns in Table 1, two facts are immediately obvious. First, Igálà pronouns mark grammatical features of number, person, and case. Second, Igálà short pronouns constitute the roots 
from which all other case forms of the pronouns are derived: \{ò-, ù-, à- $\}$ are the prefixes used to derive the nominative forms; $\{\grave{\mathrm{u}}-\}$ is the prefix in the accusative forms; while the bi-syllabic èe - is the affix in the marked genitive forms. The genitive morpheme èémorphologically looks like the demonstrative èyí which has lost the consonant segment $y$, and because of the contiguity of the remaining two vowels, a progressive assimilation applies turning è̀ $\rightarrow$ èé (see section 4.2. below).

Evidence from Table 1 also shows that each of the six personal plural pronouns in Ígálà inherently possesses a plural feature. No syntactic or morphological process is involved. In other words, there is no evidence to show that their plural feature is derived in any way.

\subsection{Plurals of Demonstratives}

Igálà short and long demonstratives (y)ilèéyi 'this' and lẹ/èéle 'that,' are structurally related. The prefix èé-, earlier noted to be a part of the morphology of marked genitive pronouns (section 4.1.), constitutes the only difference between the two forms. Given the fact that affixation is a highly productive morphological process in Igálà, it is assumed that the long emphatic forms, i.e., èé(y)i and èéle, are derived from the short $(y) i$ and $l e$ through èé- affixation, as illustrated in (21).

$\begin{array}{rll}\begin{array}{ll}\text { (21) a. èé- } \\ \text { Pref }\end{array} \text { this } & \rightarrow \text { èé(y)i } \\ \text { 'this (emphatic)' } \\ \text { b. èé- lẹ } \\ \text { Pref that }\end{array} \quad \begin{aligned} & \text { èélẹ } \\ & \text { 'that (emphatic)' }\end{aligned}$ 
74 Plural Formation Strategies in Ígálà

Two structural devices are used in Ígálà to derive the plural forms of these demonstratives. The first is by pre-merging àbó 'folk/people' to the emphatic èéyí or èéle, as in (22).
(22)

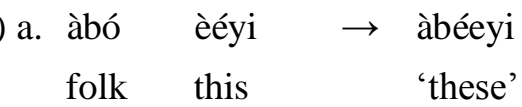
b. àbó èélẹ $\rightarrow$ àbéelẹ
folk that 'those'

The other possibility that the short forms of the demonstratives, i.e., (y) $i$ and le, may have been employed for this derivation instead of their long emphatic counterparts is not plausible for the simple reason that the output/product of the derivation, i.e., àbéeyi and àbéele contains relics of the prefix èé- which is part of èéyí and èéle not found in the short $(y) i$ and $l e$. This implies that the morphological process involved in the derivation is compounding and not prefixation. The reason for this is not far fetched: àbó is a free morpheme often used independently as a word in the grammar of the language, e.g., example (2) rewritten here as (23) for ease of reference.
(23) a. àbó
Igálà
folk/people Igala
'Igala people/folks'
b. Àbó wẹ hà?
folk/people 2sg Qst
'What about your folks/people?' or
'How are your folk/people?'


The second strategy employed in Ígálà to derive the plural of demonstratives is morpho-syntactic in nature. This involves two other word items which are equally regarded as demonstratives in the language, i.e., ékidẹi and ékìoí logically translated as 'this' and 'these' respectively. The uniformity and complexity of the derivation of these items involve complementizer phrase nominalization which uses the gerund nominalising prefix $e^{-}$, as illustrated in (24).

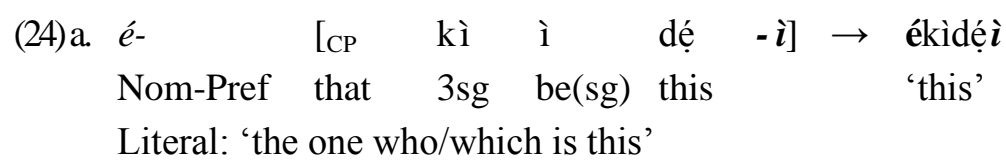

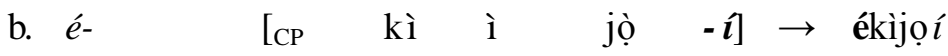 Nom-Pref that $3 \mathrm{sg}$ be(pl) this 'these'
Literal: 'the ones who/which are these'

Evidently, the number interpretation (i.e., singular 'this' or plural 'these' in these structure is determined by the contrast between the two contending verbs to be dé (sg) or jọ (pl). The prefix é- used in the derivation is a highly productive nominalising prefix in Ígálà which derives nouns from verbs or verb phrases and adjectives, as illustrated in (25).

(25)

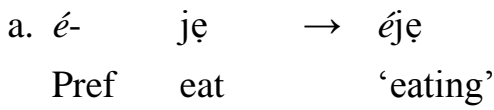
b. $e^{-}$

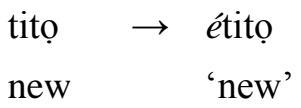




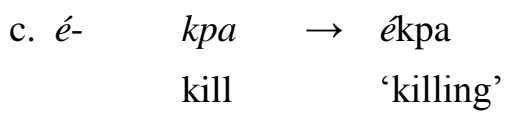

It logically follows therefore that the demonstratives ékidẹi and ékijọi are some form of noun/nominal words just like every other noun derived through é- prefixation in Igálà. However, the fact that they are referential in the manner of demonstratives evidently qualifies them to be categorized as such.

\section{Plural Marking in the Predicate}

\subsection{Identifying Ígálà Plural Predicates}

The verbs dẹ and jọ are the respective singular and plural forms of the verb 'to be' in Ígálà. They impose some kind of number restrictions on the subject argument of their clauses. Usually, dé licenses singular subjects as exemplified in (26).

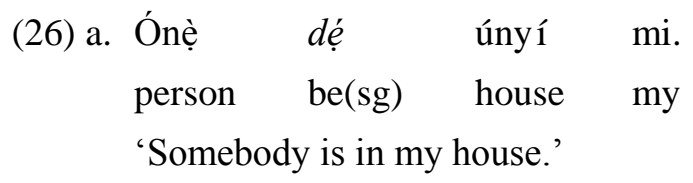

b. Ímọtọ dẹ ọ́dọ́da.

child be(sg) outside

'The child is outside.' 
c. *Àma achukọ́lọ́ dẹ ùbì únyí wẹ. $3 \mathrm{pl}$ worker be(sg) back house 2sg-gen '*Workers is at the back of your house.'

(26c) is ill-formed because the subject of dẹ is plural unlike in the well-formed $(26 \mathrm{a}, \mathrm{b})$ where the subjects are singular. On the other hand, jo regularly selects plural subjects as inherent singular nouns are never allowed as its subject. For instance, $(27 \mathrm{c}, \mathrm{d})$ are ill-formed because the subjects of $j o$ there are singular.
a. Àmónè jọ únyí mi. people be(pl) house my
'There are people in my house.'

b. Ma jo èmi.

$3 \mathrm{pl}$ be(pl) here

'They are here.'

c. *Ónẹ jọ únyí mi.

person be(pl) house my

'*There are somebody in my house.'

d. * İ jọ ọ̀mọ.

$3 \mathrm{sg} \quad \mathrm{be}(\mathrm{pl})$ there

'*She/He/It are there.'

This implies that $j o$ imposes [+PL] feature on its subject as native speakers consistently interpret such subject as plural even when it 
has no overt plural marker. For instance, ígà 'net' and únyí 'house' are assumed to be plural in (28) despite the lack of any visible plural markers in the clause.
(28)
Ígàlúnyí mi jọ í.
net/house my be(pl) this
'These are my nets/houses.'

The plural interpretation for the subjects, Ígà $m i$ and únyí $m i$, in this instance follows from the intuitive knowledge of Igala native speakers that $j o$ is a plural V. Two other verbs that are traditional assumed to be sensitive in the way they agree in number with their nominal objects are $d u$ 'to bring' (singular) and kó 'to pack' (plural) as exemplified in (29) and (30).
a. Du ólí lẹ wá.
bring tree/stick the come
'Bring that stick.'

b. ¿̀ $\mathrm{mu} \quad d u \quad$ tínyọ̀.

1sg take-3sg bring to-away

'I (took and) threw it away.'
(30)
a. Ma kó olí lẹ̀.
$3 \mathrm{pl}$ take/pack tree that
'They pack those sticks.' 
b. Kó ítébù Wá.

take/pack table come

'Bring some tables.'

c. Ajuma kó àkpàti lẹ jo ọ̀mọ.

Ajuma pack box that be(pl) there

'Ajuma took/packed those boxes there.'

As evident in (29) and (30), $d u$ selects only singular objects while $k o ́$ selects plural objects, irrespective of whether the nominal object is visibly marked for plural or not. For instance, it is only in (29c) that $k o ́$ has a marked plural object, yet all of the nominal objects of $k o ́$ in (29a-d) are interpreted as plural.

\subsection{Syntactic Formalization}

Having identified jọ, and kó as plural verbs in Ígálà, the next task is to discuss how they structurally realize their plural features with which they select appropriate arguments in the syntax of the language. Jo being a verb 'to be' is a one-place predicate. It obligatorily selects a subject argument and an optional locative adverb or preposition phrase adjunct complement. This is evident in examples (27a, b) and (28). For (27a, b), we assume an inner core VP projected by jo where the subject position is theta marked as [+theme +plural]. In other words, any argument that would be merged to jo as subject must possess these two features requirements which are clearly met in àmonẹ 'people' and the $3 \mathrm{pl} \mathrm{ma.} \mathrm{The} \mathrm{complement}$ position is superficially occupied by locative adjunct phrases únyí mi 'my house' and ọ́dọ́dá 'outside.' The syntactic projection of the V 
80 Plural Formation Strategies in Ígálà

jọ can be formalized as in (31).

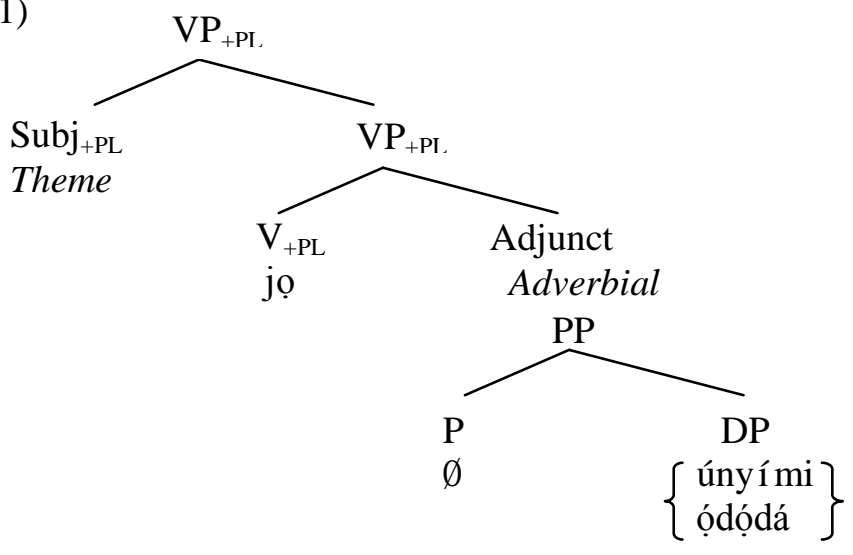

To derive the convergent clauses in (27), it is assumed that the core VP in (31) is merged directly to plural Infl head to project an I-bar. This is in order because the subject in this projection is not a volitional agent, so the outer $v P$ shell is not required. Similarly, there is no need to provide for accusative feature checking since the $\mathrm{V}$ does not select for a direct object complement. After this, the theme subject is attracted to spec-IP by $\operatorname{Infl}^{\circ}$ to satisfy its EPP features. This would result in a spec-head feature checking configuration between the plural $\operatorname{Infl}^{\circ}$ and the raised subject. Infl ${ }^{\circ}$ and the raised subject will engage in mutual feature checking and since their features (plural feature inclusive) match, the derivation survives spell-out as convergent. This clause projection is presented in (32). ${ }^{8}$

\footnotetext{
${ }^{8}$ We posit a null locative preposition head here because though Igálà has a locative P element tú as in tú ájá $\rightarrow$ tájá 'to the market' it doesn't show up phonetically in this context, yet únyí mi or ọ́dọ́da is a location in the context. This is evident in expressions like Nà á ló tú únyí ( $\rightarrow$ túnyí) $\boldsymbol{m i}$ 'I will go to my house' where tú shows up phonetically as a locative P. It is therefore opined in this study that, though
} 
(32)

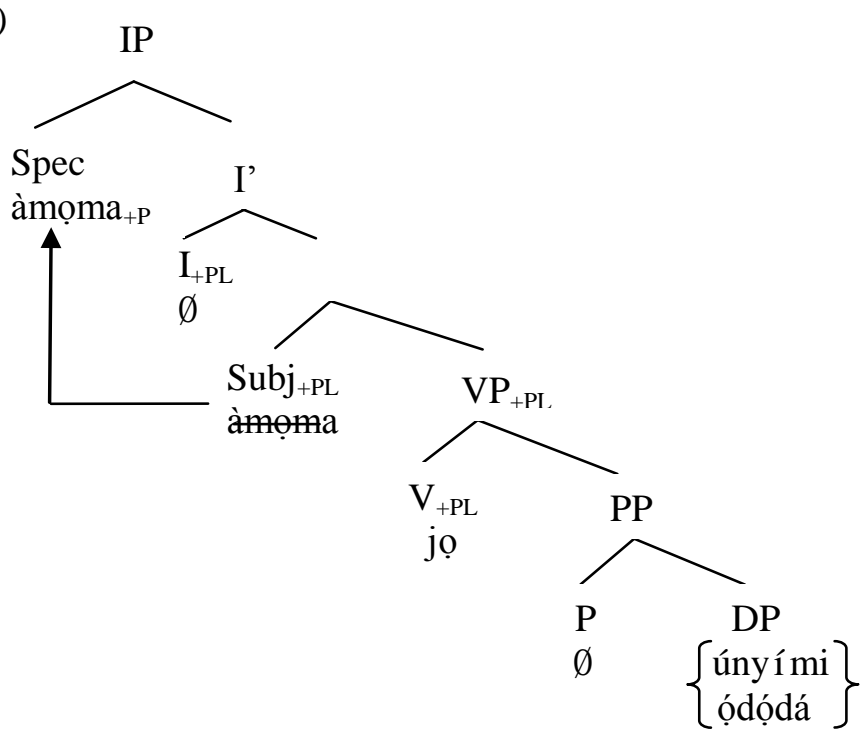

On the other hand, kó is a two-place predicate which assigns two participating thematic roles: volitional agent to subject and theme to direct object complement. It is pertinent to mention at this point that the scope of the plural feature of kó is actually restricted to its object complement. In other words, only a $[+\mathrm{PL}]$ argument can function as direct object complement of kó. The implication of this for the VP structure of this verb is that it requires an outer $v P$ shell projection to base generate its volitional agent subject and an intervening predicate phrase projection between the outer and the inner verb phrase shells to create a spec-head configuration for itself and its object to check off their accusative features. We therefore propose (33) as the structural projection of its VP.

phonetically null, the locative $\mathrm{P}$ is morphologically and syntactically present in the Ígálà clause type represented in (32). 
82 Plural Formation Strategies in Ígálà

(33)

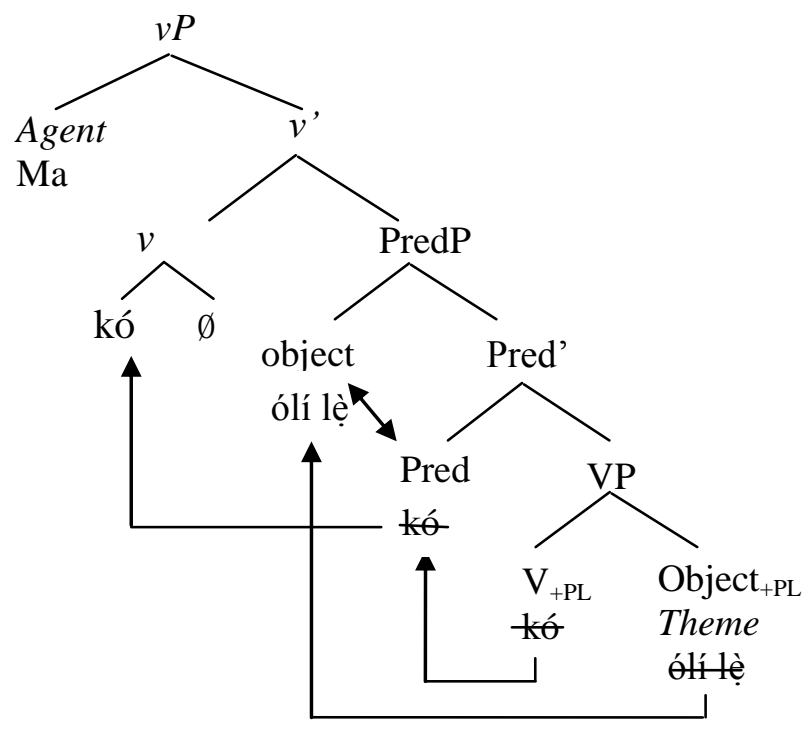

To project the full clause in (30a) based on the VP configuration in (33), the projection in (34) would suffice. 
(34)

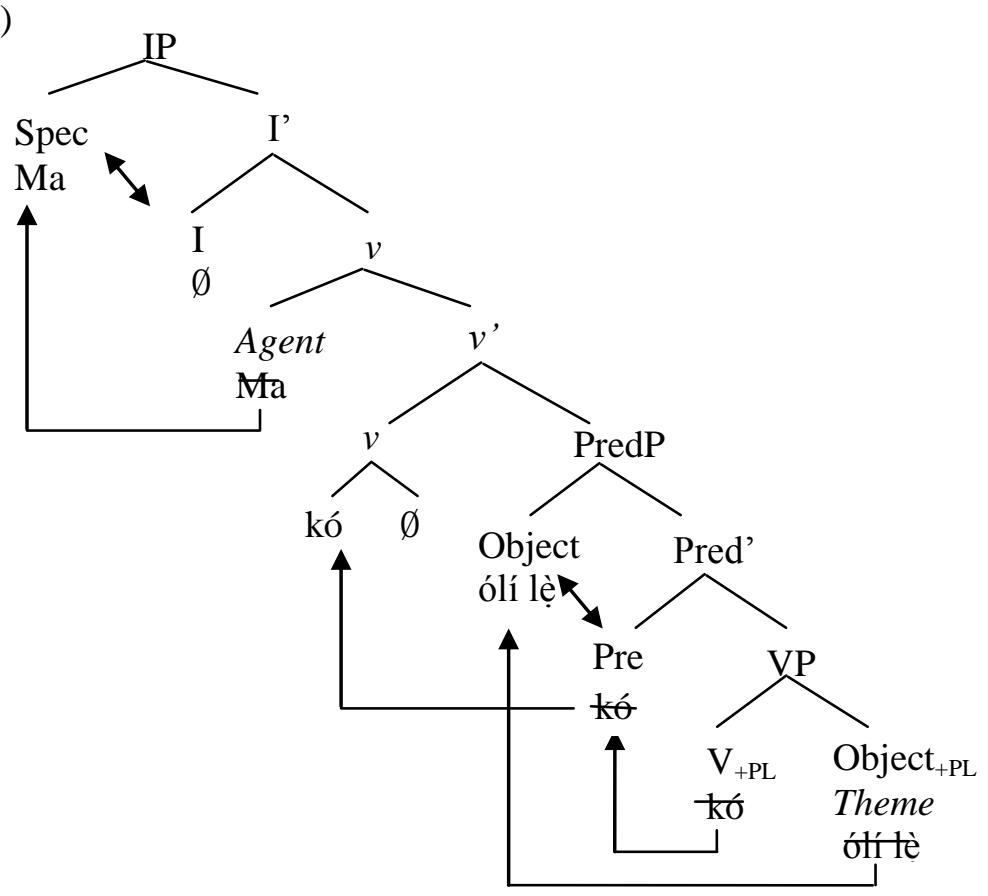

\section{Conclusions}

This paper has taken a vivid look at the various strategies employed in Ígálà grammar to derive the plural form of word expressions and the effect they bring to bear on the clause syntax of the language. It identified four devices namely, nominal compounding, full reduplication or copying of lexical root words, quantifier/numeral modification of inherent singular nouns, and syntactic verb subject and complement selection (i.e., c-selection and s-selection). It rejected the prefix analysis of earlier studies for plural 


\section{Plural Formation Strategies in Ígálà}

nouns of the àma and àbó type and show that such plural formation device and that of full reduplication are not exclusive to Ígálà as other Yoruboid languages, e.g., Yoruba, employ similar strategies to derive plural of noun. It is therefore safe relatively to conclude that Ígálà plural formation system is not so distantly different from what obtains in other Yoruboid languages.

\section{References}

Aboh, E. 2007. Focus Versus Non-Focused Wh-phrases. In K. Hartmann, E. Aboh \& M. Zimmermmann (eds.), Focus Strategies in African Languages 297-325. Berlin: Mouton.

Akinkugbe, O. 1976. An Internal Classification of the Yoruboid Group (Yoruba, Isẹkiri, Igala). Journal of West African Languages 11.1/2, 1-19. . 1978. A Comparative Phonology of Yoruba Dialects, Isekiri, and Igala. Ph.D Dissertation. University of Ibadan. Ameka, F. 2010. Information Packaging Constructions in Kwa: Micro Variation and Typology. In E. Aboh \& J. Essegbey (eds.), Topics in Kwa Syntax 141-176. Dordrecht: Springer.

Awobuluyi, O. \& F. Oyebade 1995. Denasalization in Yoruba: A

Non-Linear Approach. In K. Owolabi (ed.), Language in Nigeria: Essays in Honour of Ayo Bamgbose 16-31. Ibadan: Group Publishers Nigeria Limited.

Borer, H. 2001. Morphology and Syntax. In A. Spencer \& A. Zwicky (eds.), The Handbook of Morphology 151-189. Malden, MA: Blackwell Publishers Ltd.

Chomsky, N. 1995. The Minimalist Program. Cambridge, MA: MIT 
Press.

. 1998. The Minimalist Inquiries: the Framework. MIT Occasional Papers in Linguistics 15. . 2002. On Nature and Language. Cambridge: Cambridge University Press.

Corbett, G. 2001. Morphology and Agreement. In A. Spencer \& A. Zwicky (eds.), The Handbook of Morphology 191-205. Malden, MA: Blackwell Publishers Ltd.

Di Sciullo, A. \& E. Williams. 1987. On the Definition of Word. Cambridge, MA: MIT Press.

Kayne, R. 1994. The Antisymmetry of Syntax. Cambridge, MA: MIT Press.

Lieber, R. 1992. Deconstruction Morphology: Word Formation in Syntactic Theory. Chicago, IL: University of Chicago Press.

Okpanachi, H. 1996. An Introduction to Igala Grammar. A Lecture Handbook. Ankpa: Kogi State College of Education. 1998. Ùkọ́chẹ Íchí Ígálà: An Igala Language Lesson

Handbook. Ankpa: Kogi State College of Education.

Omachonu, G. 2001. Igala Morphological Processes. Nsukka Journal of African Languages \& Linguistics 2.1, 55-65. 2003. Animacy Hierarchy: A Case for Noun Plural Formation in Igala Language. In M. Attah et al. (eds.), Language and Literature in Education for a Better Society: The Challenges of the 21st Century 201-208. Nsukka: Great AP Express Publishers Limited.

. 2011. Derivational Processes in Igala Numeral System: Some Universal Considerations. Journal of Universal Language 12.2, 81-101.

Omamor, A. 1976. The Place of Itsekiri in Relation to Yoruba. Research Notes 7.1/2: 1-67. 
86 Plural Formation Strategies in Ígálà

Radford, A. et al. 2001. Linguistics: An Introduction. Cambridge: Cambridge University Press.

Toman, J. 2001. Word Syntax. In A. Spencer \& A. Zwicky (eds.), The Handbook of Morphology 306-321. Malden, MA: Blackwell Publishers Ltd.

Wunderlich, D. \& R. Fabri. 1995. Minimalist Morphology: An Approach to Inflection. Zeitschrift für Sprachwisssenschaft 14.2, 236-294. 